\title{
PSIKOLOGI DALAM TRADISI ILMIAH ISLAM
}

\author{
Norhidayat \\ Mahasiswa S.3 Kajian Islam Sekolah Pascasarjana UIN Syarif \\ Hidayatullah Jakarta \\ Diterima 10 Januari 2013/Disetujui 15 Juni 2013
}

\begin{abstract}
This paper described about psychology which had been discussing in the traditions of Islamic thought. Either in religious perpective, Sufi's or philosophy's, the psychology in the traditions of Islamic thought was basically different from the psychology in the tradition of western-secular thought. However the last psychology was reduced as a study of mind and behavior or mental processes, the other has been a study of soul as immaterial substansions, it was neither of body nor part of body, it would be exist whenever the body had been died and each may be repaid what it had earned.
\end{abstract}

Kata kunci: Psikologi, Religius, Sufistik, dan Filosofis

\section{Pendahuluan}

Sampai akhir abad ke-20, kajian psikologi terus mengalami perkembangan pesat dalam tradisi ilmiah Barat. Perkembangan kajian psikologi ini tak pelak lagi memunculkan berbagai aliran mulai dari psikoanalisa, behaviorisme, humanistik, hingga transpersonal psikologi. Banyak pemikir besar yang terlibat, baik sebagai pioner maupun pengembang aliran-aliran psikologi tersebut dengan bermacam varian teori yang dihasilkannya. ${ }^{1}$ Teori-teori ilmiah dari kajian psikologi Barat ini telah mempengaruhi banyak orang dan dimanfaatkan untuk berbagai kepentingan oleh banyak pihak, tidak terkecuali oleh para sarjana Muslim.

Sebagai hasil dari kajian ilmiah kemanusiaan, sebuah teori ilmiah, termasuk dalam hal ini teori-teori psikologi Barat seharusnya memang bersifat objektif dan universal sehingga tidak ada masalah digunakan oleh siapa saja. Akan tetapi, benarkah teori-teori ilmiah psikologi Barat

\footnotetext{
${ }^{1}$ Baca tentang "Kecenderungan Baru Psikologi" dalam Yadi Purwanto, Epistemologi Psikologi Islami Dialektika Pendahuluan Psikologi Barat dan Psikologi Islami (Bandung: Refika Aditama, 2007), h. 110-121. Baca juga "Sejarah Perkembangan Psikologi" dalam Abdul Rahman Shaleh \& Muhbib Abdul Wahab, Psikologi Suatu Pengantar dalam Perspektif Islam (Jakarta: Prenada Media, 2004), h. 7-39.
} 
bersifat objektif dan universal? Hal ini merupakan sebuah tanda tanya besar, karena perumusan teori-teori tersebut tak terlepas dari kerangka berpikir (mode of thought) masyarakat Barat yang sekularistik-positivistik. ${ }^{2}$

Dengan kerangka berpikir sekularistik-positivistik, kajian psikologi di Barat mengalami reduksi dan degradasi yang parah. Karena keinginannya untuk diakui sebagai disiplin ilmiah, psikologi harus rela tunduk pada paradigma positivistik, dengan membatasi objek kajiannya pada bidang-bidang empiris saja meski menanggung resiko harus kehilangan dimensi metafisiknya. ${ }^{3}$ Psikologi yang awalnya dipahami sebagai ilmu yang mempelajari tentang jiwa (the soul), belakangan tereduksi menjadi studi tentang pikiran (the mind) dan bahkan menjadi tentang perilaku dan proses mental. ${ }^{4}$

Realitas tersebut sebenarnya merupakan tragedi ilmiah bagi masyarakat modern yang seharusnya disadari, ${ }^{5}$ khususnya oleh para

${ }^{2}$ Djamaluddin Ancok dan Fuad Nashori Suroso, Psikologi Islami Solusi Islam atas Problem-problem Psikologi (Yogyakarta: Pustaka Pelajar, 1994), h. 65; Baca juga tentang "Sekularisasi Ilmu", dalam Mulyadhi Kartanegara, Menyibak Tirai Kejabilan: Pengantar Epistemologi Islam (Bandung: Mizan, 2003), h. 120-128; Baharuddin, Aktualisasi Psikologi Islami (Yogyakarta: Pustaka Pelajar, 2005), h. 31-32.

${ }^{3}$ Mulyadhi Kartanegara, Integrasi Ilmu: Sebuah Rekonstruksi Holistik (Bandung: Arasy, 2005), h. 179.

${ }^{4}$ Psychology is the scientific study of behavior and mental processes.... the original definition as the study of the soul (later, of the mind). Lihat dalam Diane E. Papalia \& Sally Wendkos Olds, Psychology (New York: Mc Graw-Hill, 1985), h. 4; Psychology is defined now as the study of mind and behavior, but even in studying the "mind", psychologist observe behavior \& draw inferences about the mental processes that produced the behavior. lihat dalam Henry L. Roediger III, (et. al), Psychology (Boston: Little Brown \& Company, 1984), h. 6.

${ }^{5}$ Baca dalam Malik B. Badri, Dilema Psikolog Muslim, terj. Siti Zainab Luxfiati dari judul asli, The Dillema of Muslim Psychologists (Jakarta: Pustaka Firdaus, 1986), h. 1-2. Menurut Malik B. Badri, sikap menerima tanpa kritik terhadap teori-teori dari Barat dan prakteknya dalam disiplin psikologi merupakan salah satu ancaman yang paling serius terhadap status ideologi Islam di antara sarjana Muslim dan ummat Islam. Sikap seperti ini hanya akan mengantarkan umat Islam terperosok ke dalam liang Biawak sebagaimana diingatkan oleh Rasulullah saw. dalam hadisnya, diriwayatkan oleh imâm

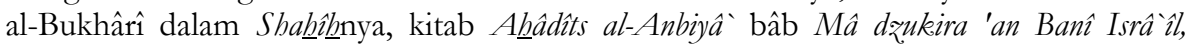
hadis nomor 3197:

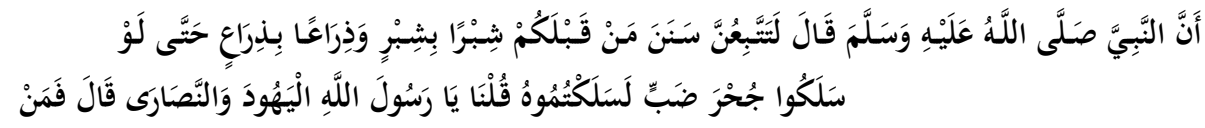

Bahwa Nabi saw. bersabda, "Kalian benar-benar akan mengikuti kebiasaan orang-orang sebelum kalian, sejengkal demi sejengkal, sehasta demi sehasta sampaisampai seandainya mereka masuk ke liang biawak pun, kalian tetap akan mengikuti 
sarjana Muslim untuk kemudian mereka kritisi dan berikan alternatifnya dengan menawarkan kajian psikologi Islam. ${ }^{6}$ Tradisi ilmiah Islam telah mewariskan khazanah yang begitu melimpah untuk kajian yang satu ini. Psikologi yang berkembang dalam tradisi ilmiah Islam memiliki perbedaan fundamental dengan psikologi yang berkembang dalam tradisi ilmiah Barat. Para ilmuan Muslim terdahulu memiliki andil yang sangat besar dalam mengembangkan kajian psikologi ini.

Pada tradisi ilmiah Islam, kajian psikologi telah berkembang setidaknya dalam tiga perspektif, yaitu: religius, sufistik, dan filosofis. ${ }^{8}$ Tulisan ini selanjutnya akan mendeskripsikan secara singkat ketiga perspektif psikologi Islam tersebut dan aspek-aspek pandangannya yang berbeda secara mendasar dengan psikologi Barat.

\section{Psikologi Religius dalam Tradisi Ilmiah Islam}

Seperti yang diungkapkan Mulyadhi Kartanegara, yang dimaksud dengan psikologi religius di sini adalah teori-teori psikologi yang dikembangkan oleh para sarjana Muslim dari perspektif agama. Pendekatan pengkajian psikologi dalam hal ini lebih banyak didasarkan atas teks-teks al-Qur'ân ataupun hadis yang dipahami secara literal. Oleh karenanya, biasa pula dinamakan dengan perspektif skriptual. ${ }^{10}$

Dalam perspektif ini, para sarjana Muslim membahas topik-topik psikologi, baik yang khas psikologi Islam, seperti tentang daya-daya jiwa manusia maupun tentang materi-materi yang dibicarakan dalam psikologi Barat dengan hampir secara penuh memanfaatkan sumber-sumber tekstual di atas, terutama dengan menggunakan term-term yang terdapat di dalamnya. Meskipun memang diakui terdapat beberapa ulama yang

mereka. (para sahabat bertanya) "apakah mereka (yang diikuti) itu, Yahudi dan Nasrani?", Nabi menjawab, (kalau bukan mereka) "Siapa lagi?"

'Beberapa sarjana menawarkan alternatif dengan menggunakan istilah "psikologi Islami", baca Hanna Djumhana Bastaman, Integrasi Psikologi dengan Islam: Menuju Psikologi Islami (Yogyakarta: Pustaka Pelajar, 1995), h. 3-13.

${ }^{7}$ Muhammad 'Utsman Najati, Jiwa dalam Pandangan Para Filosof Muslim, terj. oleh Gazi Saloom, dari judul asli al-Dirâsât al-Nafsâniyyah 'inda al-'Ulamâ' al-Muslimîn (Bandung: Pustaka Hidayah, 2002), h. 15.

${ }^{8}$ Mulyadhi Kartanegara, Psikologi Islam: Pengantar Psikologi Filosofis (Jakarta: Cipsi Publiser, 2007), h. 33.

${ }^{9}$ Mulyadhi Kartanegara, Psikologi Islam, h. 33.

${ }^{10}$ Abdul Mujib dan Jusuf Mudzakir, Nuansa-nuansa Psikologi Islam (Jakarta: RajaGrafindo Persada, 2002), h. 23. 
memanfaatkan literatur non-skriptual, seperti sastra dan filsafat. Namun tetap saja tekanan kuat mereka berikan pada kedua sumber wahyu di atas.

Ada dua kecenderungan yang berbeda dalam menggunakan perspektif religius ini, yaitu: Pertama, membahas tentang jiwa manusia terutama dengan menggalinya secara langsung dari petunjuk al-Qur ân dan hadis. Kedua, membahas tentang materi-materi psikologi seperti yang telah banyak diungkapkan dalam kajian psikologi Barat, kemudian mencoba memberikan nuansa islami, baik dengan cara mencarikan padanannya dalam kedua sumber tekstual doktrin Islam maupun dengan cara mencocok-cocokkan dengan petunjuk keduanya. Kecenderungan yang pertama, banyak dilakukan oleh ulama Muslim klasik, sedangkan kecenderungan yang terakhir lebih banyak dilakukan oleh sarjana Muslim yang telah berkenalan dengan kajian psikologi Barat. ${ }^{11}$

Model pendekatan psikologi religius atau skriptual ini telah berkembang sejak periode klasik Islam hingga saat ini. Tokoh-tokoh ulama Muslim seperti: Ibn Hazm (994-1064 M), Ibn Taimiyah (12631328 M), dan muridnya, Ibn Qayyim al-Jauziyyah (1292-1350 M) merupakan representasi yang tepat dari kelompok ulama Muslim klasik yang menggunakan perspektif psikologi religius ini.

Ketiga tokoh tersebut di atas percaya akan eksistensi jiwa, karakter immaterialitas, dan immortalitasnya (kelangsungan hidupnya). Dalam

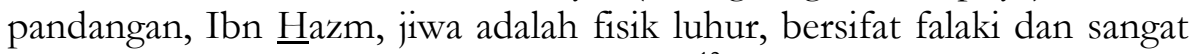
lembut, bahkan lebih lembut dari udara. ${ }^{12}$ Menurutnya, jiwa memiliki wujud sebelum menyatu dengan fisik. ia memiliki asal usul primordialnya dalam apa yang biasa disebut sebagai perjanjian primordial, seperti dinyatakan Allah swt. dalam Q.S. al-A'râf :172,

\footnotetext{
${ }^{11}$ Contoh perspektif psikologi religius dengan kecenderungan yang kedua, baca misalnya, karya Muhammad 'Utsmân Najatî, Al-Qur'ân wa 'Ilm al-Nafs (Kairo: Dâr al-

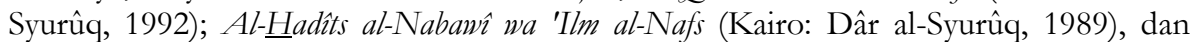
Achmad Mubarok, Psikologi Qur'ani (Jakarta: Pustaka Firdaus, 2001). Karya yang terakhir ini berasal disertasi penulisnya di program pascasarjana UIN Syarif Hidayatullah Jakarta tahun 1999, dengan judul, Konsep Nafs dalam Al-Qur ân (Suatu Kajian tentang Nafs dengan Pendekatan Tafsir Maudhû̀

${ }^{12}$ Baca dalam Muhammad 'Utsman Najati, Jiwa dalam Pandangan, h. 184.
} 


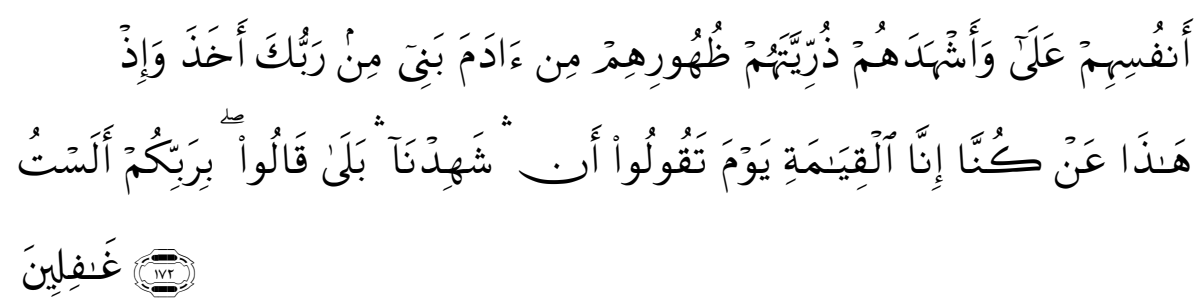

Dan (ingatlah) ketika Tuhanmu mengeluarkan dari sulbi (tulang belakang) anak cucu Adam keturunan mereka dan Allah mengambil kesaksian terhadap roh mereka (seraya berfirman), "Bukankah Aku ini Tuhanmu?" Mereka menjawab, "Betul (Engkau Tuhan kami), kami bersaksi." (Kami lakukan yang demikian itu) agar di hari kiamat kamu tidak mengatakan, "Sesungguhnya ketika itu kami lengah terhadap ini."

Tetapi, katanya lebih lanjut, ketika jiwa bersatu dengan fisik, jiwa menjadi tersiksa seakan-akan ia terjerumus dalam lumpur kotor, sehingga ia menjadi lupa dengan masa lalunya karena kesibukannya dengan tubuh. ${ }^{13}$ Tugas manusia, menurut Ibn $\underline{\mathrm{H}} a z m$, adalah membebaskan dirinya dari segala kotoran dan kekeringan tubuh, hanya dengan cara itu jiwa bisa mencapai pandangan yang jernih dan ilmu yang benar. Jika jiwa terbebas dari kekeringan dan kotoran tubuh, maka ia akan menjadi pandangan yang paling bening dan ilmu yang paling benar, sebagaimana halnya sebelum menyatu dengan tubuh. Dalam Q.S. Qâf :22 dinyatakan,

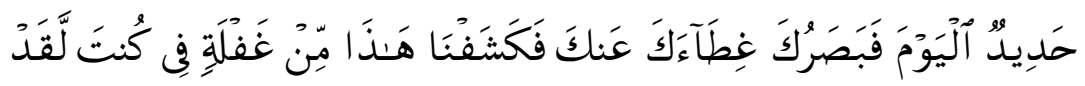

(II)

Sungguh, kamu dahulu lalai tentang (peristiwa) ini, maka Kami singkapkan tutup (yang menutupi) matamu, sehingga penglihatanmu pada hari ini sangat tajam.

Tentang immortalitas jiwa, dengan tegas Ibn hazm mengatakan bahwa jiwa bersifat abadi (dalam arti bertahan hidup) setelah kematian. Sebagai psikolog religius, Ibn hazm percaya bahwa kehidupan akhirat tidak bersifat ruhani semata-mata; tetapi menyandang fisikalitas tertentu dengan indera dan daya-daya jiwa yang dikandungnya. Menurutnya,

13'Utsman Najati, Jiwa dalam Pandangan, h. 184. 
indera dan pengetahuannya tidaklah hilang setelah kematian. Bahkan di sana, inderanya menjadi lebih benar dan pengetahuannya menjadi lebih sempurna dari sebelumnya seperti disebutkan dalam Q.S. Qâf : 22 sebelumnya. Di alam akhirat ini juga, kehidupan jiwa yang terdiri dari penginderaan, gerak dan keinginan abadi akan menjadi bentuk yang lebih sempurna. Konsep eskatologisnya ini tentu saja disandarkan pada otoritas kitab suci, yaitu al-Qur'an, Dalam (Q.S. al-'Ankabût : 64), Allah swt. berfirman,
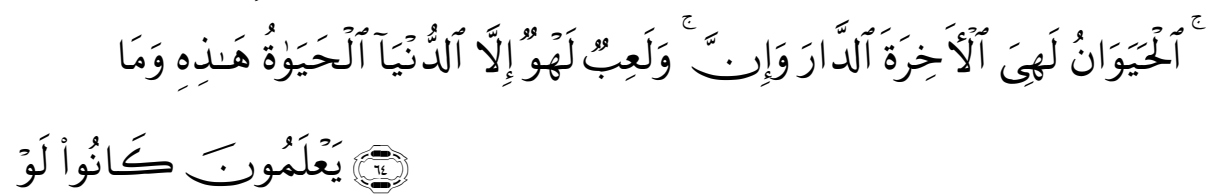

Dan kehidupan dunia ini hanya senda gurau dan permainan. Dan sesungguhnya negeri akhirat itulah kehidupan yang sebenarnya, sekiranya mereka mengetahui.

Senada dengan pandangan Ibn $\underline{H}$ azm, pendapat yang diajukan oleh Ibn Taimiyah, seorang teolog bermazhab Hambali yang dikenal sangat tajam kritiknya terhadap para sufi dan filosof. Tentang hakikat jiwa, Ibn Taimiyah menyatakan bahwa jiwa tidak tersusun dari substansi-substansi yang terpisah, bukan pula terdiri dari bentuk dan materi. Jiwa, menurutnya, bukan fisik dan bukan pula esensi yang merupakan sifat yang bergantung pada yang lain. "Sesungguhnya jiwa," katanya berdiri sendiri dan tetap ada setelah berpisah dari badan ketika kematian datang. ${ }^{14}$

Seperti halnya Ibn $\underline{H} a z m$, Ibn Taymiyah juga menyandarkan teori jiwanya pada otoritas al-Qur'an dan hadits. Ibn Taimiyah percaya bahwa kata ruh juga digunakan untuk pengertian jiwa. "Ruh yang mengatur badan yang survive setelah kematian, adalah ruh yang ditiup (Tuhan) kepada (badan)nya, dan ialah jiwa yang meninggalkan badan melalui proses kematian. Mengutip sebuah hadits untuk menguatkan pendapatnya tersebut. "Sesungguhnya Allah menggenggam ruh kita sekehendak-Nya dan mengembalikannya sekehendak-Nya. ${ }^{15}$ Ia juga mengutip al-Qur'an yang berkaitan dengan itu (Q.S. al-Zumar : 42), Allah swt. berfirman,

${ }^{14}$ 'Utsman Najati, Jiwa dalam Pandangan, h. 342.

15'Utsman Najati, Jiwa dalam Pandangan, h. 342. 


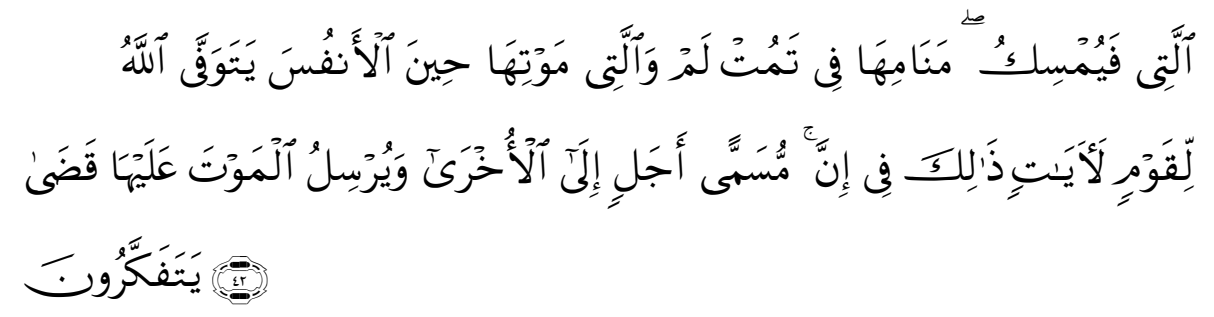

Allah memegang nyawa (seseorang) pada saat kematiannya, dan nyawa (seseorang) yang belum mati ketika dia tidur; maka Dia tahan nyawa (orang) yang telah Dia tetapkan kematiannya, dan Dia lepaskan nyawa yang lain sampai waktu yang ditentukan. Sungguh, pada yang demikian itu terdapat tanda-tanda (kebesaran) Allah bagi kaum yang berpikir.

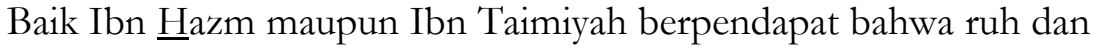
jiwa adalah dua nama dari sesuatu yang sama dan satu. Ketika Allah swt, dalam Q.S. al-Isrâ : 85 berfirman,

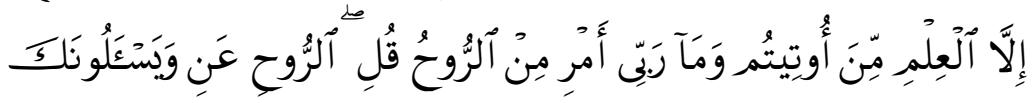

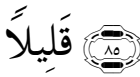

Dan mereka bertanya kepadamu (Muhammad) tentang ruh. Katakanlah, "Ruh itu termasuk urusan Tuhanku, sedangkan kamu diberi pengetahuan hanya sedikit."

maka yang dimaksud adalah ruh dan juga jiwa. ${ }^{16}$ Ibn Taimiyah menambahkan, bahwa terkadang ia disebut jiwa lantaran sifatnya yang mengatur badan, dan disebut ruh karena sifatnya yang lembut. ${ }^{17}$

Adapun tentang akal, pendapat keduanya juga hampir serupa, Ibn Hazm menyatakan bahwa akal merupakan aksiden yang terbawa dalam jiwa. Jadi bukan sebuah substansi. Sebagai buktinya adalah kenyataan bahwa akal dapat menerima sifat "paling kuat dan paling lemah," sehingga orang dapat mengatakan bahwa akal yang satu lebih kuat daripada yang lain. Sedangkan substansi tidak bisa punya lawan, karena lawan hanya ada pada aksiden. Oleh karena itu dapatlah disimpulkan bahwa akal bukanlah substansi, seperti yang dinyatakan oleh para filosof.

16'Utsman Najati, Jiwa dalam Pandangan, h. 185.

${ }^{17}$ 'Utsman Najati, Jiwa dalam Pandangan, h. 342. 
Akal, kata Ibn $\underline{H} a z m$, lebih lanjut, merupakan perbuatan jiwa, aksiden yang terkandung di dalam jiwa, atau merupakan salah satu daya jiwa. ${ }^{18}$

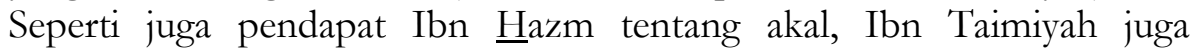
menolaknya sebagai sebuah substansi yang berdiri sendiri. Menurutnya, akal merupakan sesuatu yang ada pada orang yang berakal, apakah ia disebut aksiden atau sifat, tapi bukan sebuah entitas yang berdiri sendiri, baik yang disebut substansi, esensi atau yang lain. ${ }^{19}$

Selain kedua tokoh ulama klasik di atas, tokoh lainnya yang juga mewakili pandangan religius tentang psikologi adalah Ibn Qayyim alJauziyyah (w. 1350), yang dikenal sebagai pemikir sufi, murid Ibn Taimiyah. Setelah menepis berbagai definisi para pemikir sebelumnya, Ibn Qayyim mengatakan bahwa jiwa adalah substansi yang bersifat nurani, berada di tempat yang tinggi, lembut, ia akan tetap hidup dan dinamis (nûrânî 'alawî khafîf bayy mutabarrik). Ia menembus substansi anggota tubuh dan mengalir bagaikan air atau minyak zaitun atau api di dalam kayu bakar. Selama anggota badan dalam keadaan baik untuk menerima pengaruh yang melimpah di atasnya dari jisim yang lembut ini, maka jisim yang lembut ini akan memberinya rasa, gerak, dan keinginan. ${ }^{20}$

Ibn Qayyim mengklaim bahwa pendapatnya tentang jiwa didasarkan kepada al-Qur ân, hadis, ïmâ' sahabat, argumentasi akal dan fitrah. Dia menyebutkan banyak ayat al-Qur'ân dan hadis yang menunjukkan kebenaran pendapat tentang jiwa ini. Ibn Qayyim menjelaskan, bahwa sebenarnya jiwa itu satu, tapi memiliki tiga sifat dan dinamakan dengan sifat yang mendominasinya. Ada jiwa yang disebut nafsu ammârah yaitu nafsu yang menyuruh kepada keburukan. Dalam Q.S. Yûsuf : 53, Allah swt. berfirman,
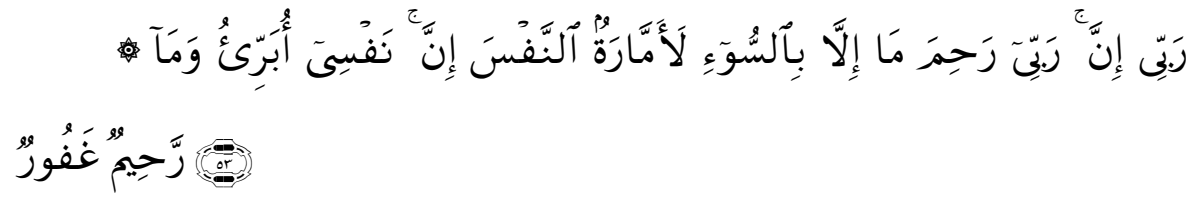

Dan aku tidak (menyatakan) diriku bebas (dari kesalahan), karena sesungguhnya nafsu itu selalu mendorong kepada kejahatan, kecuali (nafsu) yang diberi rahmat oleh Tuhanku. Sesungguhnya Tuhanku Maha Pengampun, Maha Penyayang.

${ }^{18}$ 'Utsman Najati, Jiwa dalam Pandangan, h. 185

${ }^{19}$ 'Utsman Najati, Jiwa dalam Pandangan, h. 344.

${ }^{20}$ 'Utsman Najati, Jiwa dalam Pandangan, h. 359-360. 
Ada nafsu lawwamah yang selalu mencela, selalu ragu-ragu antara menerima dan mencela secara bergantian, seperti diisyaratkan istilahnya dalam Q.S. al-Qiyâmah : 1-2,

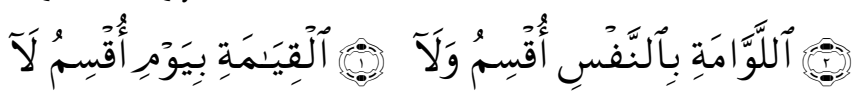

Aku bersumpah dengan Hari Kiamat dan aku bersumpah demi jiwa yang selalu menyesali (dirinya sendiri).

Dan terakhir adalah jiwa yang disebut nafsu muthma'innah (jiwa yang tenang) karena ketenangannya dalam beribadah, ber-mahabbah, berinabah, bertawakal, beserta keridhaan dan kedamaiannya dengan Allah. Dalam Q.S. al-Fajr : 27-30, Allah swt. berfirman,

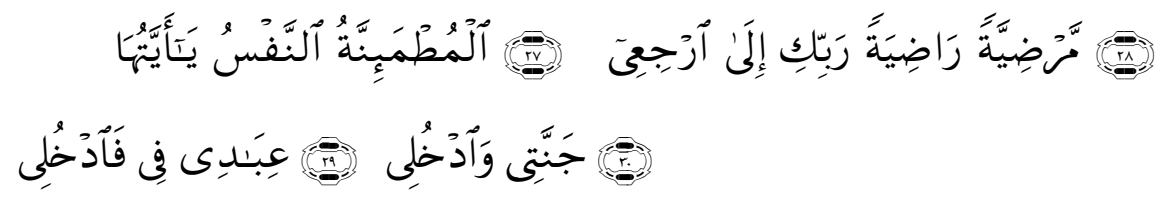

Wahai jiwa yang tenang! Kembalilah kepada Tuhanmu dengan hati yang ridha dan diridhai-Nya. Maka masuklah ke dalam golongan hamba-hamba-Ku, dan masuklah ke dalam surga-Ku.

Tujuan perkembangan jiwa manusia, menurut Ibn Qayyim adalah tercapainya jiwa muthma'innah, yang merupakan kesempurnaannya. Di sini terlihat bahwa bagi Ibn Qayyim, jiwa (ruh) dan nafs (nafsu) digunakan dalam arti atau pengertian yang sama. ${ }^{21}$

Selain berbicara tentang jiwa yang ia samakan dengan nafsu, Ibn Qayyim juga berbicara tentang hati (qalb) dan akal. Baginya, hati adalah raja yang menggunakan seluruh alat tubuh. Hati merupakan alat tubuh yang paling terhormat, sendi kehidupan, sumber ruh hewani, kehangatan instink, tempat penambangan akal, ilmu, impian, kehormatan, keberanian, kesabaran, ketekunan, kecintaan, keridhaan, kemarahan dan seluruh sifat kesempurnaan lainnya. Oleh karena itu, boleh dikata bahwa seluruh anggota tubuh, baik yang bersifat lahir maupun batin beserta energi yang dimilikinya adalah pasukan hati. Adapun yang dimaksud hati di sini bukanlah daging yang sama-sama dimiliki oleh hewan juga, tetapi yang dimaksud adalah mind atau pikiran $(l u b b) .{ }^{22}$

21'Utsman Najati, Jiwa dalam Pandangan, h. 360.

22'Utsman Najati, Jiwa dalam Pandangan, h. 362-363. 
Adapun akal dipandang Ibn Qayyim sebagai alat atau timbangan setiap ilmu untuk mengetahui yang benar dan salah. Sedangkan tempat akal bukanlah di otak, tetapi, berdasarkan pada ayat Qur'an (al-ㅍaj): 46), terletak di hati, sedangkan cabang buahnya terletak di otak. ${ }^{23}$

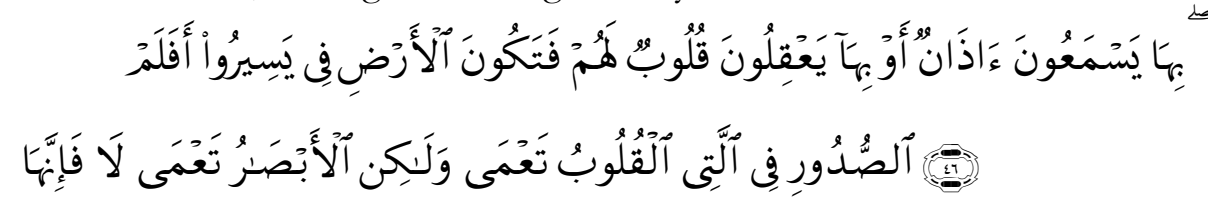

Maka tidak pernahkah mereka berjalan di bumi, sehingga hati (akal) mereka dapat memahami, telinga mereka dapat mendengar? Sebenarnya bukan mata itu yang buta, tetapi yang buta ialah hati yang di dalam dada.

Demikian pandangan dari beberapa tokoh ulama Muslim klasik tentang jiwa dengan menggunakan perspektif religius. Dari sini terlihat jelas karakteristiknya, yaitu mendasarkan pandangannya pada sumbersumber wahyu secara tektual, menekankan immaterialitas jiwa dan immortalitasnya. Keyakinan akan hal-hal ini, dipandang oleh para psikolog religius penting, karena ia akan menjadi landasan bagi keyakinan dan kebermaknaan akan hari akhir. Karena kalau seseorang tidak percaya pada keberlangsungan hidup (immortalitas) jiwa setelah kematian, maka akan runtuh dan tak bermaknalah segala keyakinannya akan hari akhir. Siapa yang akan mempertanggungjawabkan segala tindakan manusia di hari nanti. Kalau jiwanya mati atau berakhir pada peristiwa kematian.

\section{Psikologi Sufistik dalam Tradisi Ilmiah Islam}

Dalam tradisi ilmiah Islam, kaum sufi telah lama dikenal mengembangkan psikologi, bahkan mereka sudah terbiasa berpraktek sebagai psikolog terapan. ${ }^{24}$ Di dunia tasawuf, kata Mulyadhi Kartanegara, psikologi, memang tidak dikembangkan terutama untuk tujuan teoritis, melainkan untuk tujuan transformasi jiwa. Karena bagi para sufi, tercapainya transformasi jiwa adalah merupakan tujuan menuntut sebuah

23'Utsman Najati, Jiwa dalam Pandangan, h. 362.

${ }^{24}$ Di antara ulama sufi klasik yang menggunakan perspektif psikologi sufistik adalah seperti Abû Hâmid al-Ghazâlî (w. 1111 M), Jalâluddin Rûmî (w. 1273 M), dan Syekh 'Abd al-Razzâq Kasyanî (w. 1335 M). Baca dalam Mulyadhi Kartanegara, Psikologi Islam, h. 38-40; Abdul Mujib dan Jusuf Mudzakir, Nuansa-nuansa Psikologi Islam, h. 32. 
ilmu. Ilmu yang tidak menghasilkan sebuah transformasi jiwa akan dipandang rendah, betapapun canggihnya ia secara teoritis. ${ }^{25}$

Psikologi dalam perspektif sufi didasarkan atas prosedur intuitif, ilham, dan cita-rasa (dzauq). Prosedur tersebut dilakukan dengan terus melakukan riyâdhah melalui proses penyucian diri (tadrkiyah al-nafs) guna menajamkan struktur kalbu. Dengan cara tersebut, mereka berharap

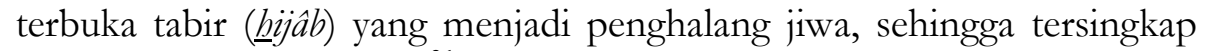
hakikat segala sesuatunya. ${ }^{26}$

Sekurang-kurangnya terdapat empat karakteristik yang dapat dipahami dari pendekatan psikologi sufistik ini, yaitu: 1) bahwa kaum sufi lebih mengutamakan aspek-aspek perasaan (feeling), sehingga sulit dideskripsikan secara ilmiah; 2) dalam kondisi neurotik, justru para sufi meyakini bahwa dirinya telah menggapai alam hakikat, sehingga mereka memperoleh pengetahuan ilham; 3) kondisi puncak yang diperoleh seorang sufi bersifat sementara dan mudah sirna, meskipun hal itu menimbulkan kesan dan ingatan yang mendalam dan tak terlupakan; dan 4) apa yang diperoleh dan dirasakan merupakan anugerah yang tidak dapat diusahakan, sebab pengalaman mistik tersebut menggantungkan diri pada kekuatan super natural yang menguasainya. ${ }^{27}$ Seperti halnya psikologi religius, psikologi sufistik ini juga selalu berusaha merujuk teori-teori yang dikembangkan dan dipraktekkannya kepada wahyu. Hanya saja, kaum sufi pada umumnya tidak memahami wahyu secara tekstual, melainkan dengan menggunakan ta'wîl untuk menyingkap isyarat-isyarat batinnya.

Dalam sejarah panjang pemikiran tasawuf memang akan lebih banyak dijumpai kaum sufi yang melakukan praktek terkait dengan terapi kejiwaan ketimbang mereka yang berupaya secara sengaja merumuskan teori-teori tentang psikologi, namun demikian, uraian tentang teori-teori psikologi yang telah mereka kembangkan bukan berarti tidak dapat ditemukan. Uraian mereka, menurut Robert Frager, berkisar pada tiga konsep dasar kejiwaan, yaitu tentang hati, diri (nafs), dan jiwa (rûh $) \cdot{ }^{28} \mathrm{Di}$ antara tokoh ulama sufi klasik yang banyak membahas tentang konsepkonsep dasar kejiwaan tersebut adalah Abû Hâamid al-Ghazâlî (w. 1111

${ }^{25}$ Mulyadhi Kartanegara, Psikologi Islam, h. 38.

${ }^{26}$ Abdul Mujib dan Jusuf Mudzakir, Nuansa-nuansa Psikologi Islam, h. 26.

${ }^{27}$ Abdul Mujib dan Jusuf Mudzakir, Nuansa-nuansa Psikologi Islam, h. 28.

${ }^{28}$ Robert Frager, Hati, Diri, \& Jiwa:Psikologi Sufi untuk Transformasi, terj. oleh Hasmiyah Rauf dari judul asli, Heart, Self, \& Soul, The Sufi Psychology of Growth (Jakarta: Serambi, 2005), h. 29. 
M), Jalâluddin Rûmî (w. 1273 M), dan Syekh 'Abd al-Razzâq Kasyanî (w. $1335 \mathrm{M})$.

Dari sejumlah penjelasan sufi tentang jiwa, menurut Mulyadhi Kartanegara, penjelasan 'Abd al-Razzaq Kasyani (w. 1335) adalah yang paling jelas menerangkan struktur jiwa manusia. Dalam pandangan Kasyani, terdapat dua unsur yang paling fundamental dan orisinal dalam diri manusia, yaitu: tanah (turab) dan rub (jiwa). Namun karena keduanya merupakan dua substansi yang sangat berlainan sifat dasarnya maka keduanya tidak bisa saling berhubungan. Tuhan kemudian menciptakan unsur ketiga yang dapat mempertemukan keduanya yang disebut nafs (jiwa), dan karena itu berada tepat di antara keduanya. Dalam bukunya Isthilâhât al-Shufiyyah, Kasyani menjelaskan definisi serta kedudukan hati sebagai berikut:

Hati adalah substansi yang bercahaya dan terpisah (terletak) antara ruㅡ dan jiwa (nafs). Melalui hatilah kemanusiaan yang sejati (al-insaniyyah) terealisir (tabaqquq). Para filosof mangacu padanya sebagai "jiwa rasional." Rub adalah dimensi batinnya, sedangkan jiwa hewan (nafs) adalah tunggangannya serta dimensi lahirnya. Nafsu (jiwa) ini terletak antara ia (hati) dan badan. Dengan demikian dapat dilihat kedudukan hati (qalb) yang berada pada posisi tengah antara jiwa (rub ) dan diri atau (nafs). Di bawah nafs terdapat badan, dan di atas rub ada Tuhan. Selain itu alKasyani juga berbicara tentang akal, yang diletakkan antara ruh dan hati, dan shudur (dada) yang terletak antara hati dan nafs (diri). ${ }^{29}$

Istilah jiwa (rub ) dan hati (qalb) dalam terminologi sufi terkadang digunakan secara bergantian. Al-Ghazali, misalnya, menyebut jiwa (ruh) dengan hati. Dalam Kimia-yi Sa'adat ia mengatakan: "Sedangkan mengenai realitas hati - benda apakah itu dan apakah sifat-sifat khususnya Hukum wahyu tidak memberikan izin [untuk membahas ini]. Itulah sebabnya Rasulullah tidak menjelaskannya, sebagaimana firman Tuhan, dalam Q.S. al-Isrâ : 85,

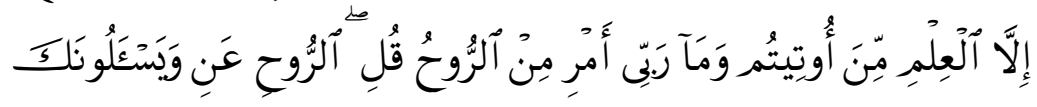

\section{قَلِيَا}

"Mereka bertanya padamu tentang ruh. Katakanlah, "Ruh itu adalah urusan Tuhanku." Jadi jelas bahwa bati yang dimaksud di sini adalah ruh. Ada juga yang menyatakan bahwa ia adalah jiwa, tetapi karena

\footnotetext{
${ }^{29}$ Lihat dalam Mulyadhi Kartanegara, Psikologi Islam, h. 40-41.
} 
fungsinya yang berbeda-beda sehingga diberi nama yang berbeda-beda pula. Misalnya ketika jiwa mengarahkan dirinya kepada Tuhan maka ia disebut ruh. Ketika ia melakukan perenungan atau kontemplasi maka ia disebut akal. Ketika ia menerima iluminasi serta ilham atau mukasyafah, maka ia disebut hati, dan ketika ia ingin berhubungan, atau mengarahkan dirinya pada badan, maka ia disebut nafsu. ${ }^{30}$

Pada akhirnya, jiwa, dalam perspektif psikologi sufistik, meskipun dijelaskan dengan term yang berbeda-beda, sebenarnya terdapat suatu benang merah yang penting dan merupakan semacam kesepakatan di kalangan para sufi, yaitu bahwa jiwa manusia, apakah disebut hati, akal atau ruh, ia bersifat rohani, bukan jasmani. Jiwa ini, seperti disimpulkan al-Ghazali, tidaklah bersifat jasmani atau bukan juga aksiden sebagaimana sering dikonsepsikan para psikolog melainkan sebuah substansi immaterial, bersifat malakuti dan bahkan ilahiyyah. Dan karena itu tidak akan hancur pada saat kematian. Jiwa bukan otak ataupun fungsi neurologis otak, tetapi ia substansi immaterial yang tidak turut hancur bersama hancurnya otak manusia, tetapi justru akan terus "survive" setelah kematian untuk memetik hasil kerjanya selama karir dunianya ini, di alam akhirat, sebagaimana didoktrinkan oleh agama.

\section{Psikologi Filosofis dalam Tradisi Ilmiah Islam}

Tidak diragukan lagi, bahwa hampir semua filosof Muslim mulai al-

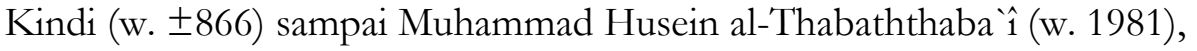
ada membahas tentang jiwa dalam karya-karya mereka. Pembahasan psikologi dari para filosof tersebut tentu saja lebih mengutamakan pendekatan rasional ketimbang dalil-dalil wahyu secara tekstual, seperti yang dilakukan para teolog dalam perspektif psikologi religius. Dengan pendekatan rasionalnya dan argumentasi-argumentasi yang didasarkan logika, konsep-konsep psikologi filosofis yang diajukan oleh para filosof Muslim sebenarnya memiliki keunggulan tersendiri, yaitu dapat dinikmati oleh kalangan yang lebih luas meski berbeda-beda keyakinan agamanya.

Di antara diskursus psikologi yang dibicarakan oleh para filosof Muslim dalam karya-karya mereka adalah tentang akal manusia. Kemudian tentang jiwa dan tingkatannya; bukti-bukti rasional (ilmiah) tentang keberadaan jiwa; immortalitas jiwa dan ketidakmungkinannya untuk dibagi; Dilanjutkan dengan pertanyaan di manakah jiwa sebelum masuk ke dalam tubuh; masuknya jiwa ke dalam tubuh. Selanjutnya

${ }^{30}$ Baca dalam Mulyadhi Kartanegara, Psikologi Islam, h. 42; 'Utsman Najati, Jiwa dalam Pandangan, h. 209-210. 
diteruskan dengan diskusi tentang tubuh dan indera; dengan pembicaraan masing-masing dari panca indera; indera rasa, penciuman, penglihatan dan pendengaran. Diskusi indera ini dilanjutkan dengan diskusi tentang daya mutakhayyilah (imajinasi) daya fikir, daya ingat, (daya memori), daya kreatif dan instink (nuz'iyyah). Dalam diskusinya tentang jiwa, para filosof juga membahas tentang pembagian jiwa, jiwa hewani, jiwa rasional dan berpisahnya jiwa dari badan. Tentang bagaimana nasib jiwa setelah kematian, atau apa yang sering disebut sebagai eskatologi, dan ini meliputi, keabadian jiwa setelah perpisahannya dengan badan; buktibukti sekitar ketidak-fanaan jiwa; tempat kembali jiwa setelah berpisah dengan badan; dilanjutkan tentang kebahagiaan jiwa dan kesenangannya dan ditutup dengan diskusi tentang realitas kebahagiaan. ${ }^{31}$

Dari topik-topik tersebut di atas, soal kerohanian jiwa, ketidakmampuannya untuk dibagi, perbedaannya dengan badan, kelangsungan hidupnya setelah kematian, merupakan topik-topik favorit dalam sebagian besar tulisan para filosof Muslim. Hal ini mengindikasikan betapa mereka telah sepakat tentang karakter immaterialitas jiwa, realitas dan keabadiannya, atau kelangsungan hidupnya setelah kematian (berpisahnya dari badan). Keyakinan ini tentunya ditopang oleh seperangkat dalil-dalil logis (burhânı) yang sangat lengkap dan mendalam. Jadi semacam anti-tesis dari apa yang telah dikemukakan oleh para psikolog modern.

Berikut ini akan dikemukakan beberapa argumen para filosof Muslim untuk menetapkan eksistensi dan sekaligus immaterialitas jiwa. Dalam rangka membuktikan eksistensi dan sekaligus immaterialitas jiwa, Ibn Miskawaih (w. 1030) misalnya, dalam kitabnya yang terkenal, Tahdરૃ̨̂ al-Akblaq mangatakan bahwa ada sesuatu pada diri manusia yang tidak fisik, karena ia memiliki karakter yang berbeda dengan fisik. Menurutnya, benda fisik hanya bisa menerima sebuah bentuk pada saat yang sama. Kalau bentuk baru ditambahkan kepadanya maka bentuk baru tersebut tidak bisa diterimanya, kecuali kalau bentuk lamanya telah dihancurkan. Ini bisa dilihat misalnya pada lilin yang telah menerima satu cetak koin. Ia tidak mungkin menerima cetak yang lainnya, kecuali ia menghancurkan bentuk yang lama. Manusia, tegasnya, berbeda dengan lilin, manusia kadang bisa menerima berbagai bentuk dalam jumlah yang banyak, misalnya ide-ide atau esensi-esensi dari benda-benda atau entitas-entitas fisik maupun non-fisik, tanpa mengubah bentuk dirinya sendiri. Dan ini

\footnotetext{
${ }^{31}$ Baca dalam Mulyadhi Kartanegara, Psikologi Islam, h. 45.
} 
jelas bukan karakter dari benda fisik seperti telah dijelaskan sebelumnya. Oleh karena itu, ia menyimpulkan mesti ada dalam diri manusia yang bukan fisik, bukan juga bagian atau gabungan dari bagian-bagian fisik. Inilah yang ia sebut jiwa yang mesti ada pada diri manusia dan mesti bersifat ruhani/non-fisik. ${ }^{32}$

Argumen lain tentang eksistensi dan immaterialitas jiwa juga telah diajukan oleh al-'Amiri, seorang filosof Muslim abad kesepuluh dari Khurasan. Dalam kitabnya yang terkenal, al-Amad 'ala al-Abad ia berkata, "Dalam kegiatan psikologis telah dibuktikan bahwa fakultas rasional manusia mampu, setelah dibantu oleh daya imajinasinya, memikirkan sesuatu yang sama sekali abstrak (al-mujarradab), yakni konsep yang tidak punya kaitan apapun dengan entitas-entitas fisik, seperti tentang esensi, kesan dan lain-lain. Sebagaimana diketahui, bahwa sesuatu itu bisa dipahami hanya oleh sesuatu yang memiliki unsur yang sama. Oleh karena itu, entitas-entitas immaterial tentunya hanya bisa dipahami oleh sesuatu yang bersifat immaterial juga. Karena tidak mungkin bagi entitas yang sama sekali fisik untuk bisa memahami hal-hal yang bersifat nonfisik." "Karena akal manusia mampu memikirkan objek-objek yang immaterial, dan karena yang immaterial tidak bisa dipahami kecuali oleh yang immaterial juga maka, "al "Amiri menyimpulkan, "akal sebagai jiwa manusia haruslah (ada dan) bersifat immaterial.",33 Selain Ibn Miskawaih dan al-'Amiri, Ibn Sina (w. 1037) dalam kitabnya yang berjudul Al-Najâh juga sampai kepada kesimpulan yang sama tentang immaterialitas jiwa. Menurutnya, karena jiwa manusia (akal) mampu bertindak tanpa alat jasmani, maka ia haruslah juga bersifat immaterial. ${ }^{34}$

Adapun yang dimaksud dengan immaterialitas jiwa itu sendiri, artinya bahwa jiwa tidak bersifat material, yakni tidak memiliki sifat-sifat atau karakter yang biasa dan bisa diterapkan pada materi. Pernyataan bahwa jiwa merupakan substansi immaterial ini tidak saja dinyatakan oleh ketiga filosof Muslim di atas, tetapi hampir oleh seluruh filosof Muslim karena maknanya yang sangat penting. Berlainan sekali dengan pendapat para psikolog modern yang telah menolak keberadaan jiwa sebagai sesuatu yang immaterial, para filosof Muslim justru berpendapat bahwa

\footnotetext{
${ }^{32}$ Baca dalam Mulyadhi Kartanegara, Psikologi Islam, h. 49-50; 'Utsman Najati, Jiwa dalam Pandangan, h. 87-88.

${ }^{33}$ Baca dalam Mulyadhi Kartanegara, Psikologi Islam, h. 51.

${ }^{34}$ Baca dalam Mulyadhi Kartanegara, Psikologi Islam, h. 52; 'Utsman Najati, Jiwa dalam Pandangan, h. 170.
} 
jiwa itu harus ada pada diri manusia dan bersifat immaterial, karena itu ketika terlepas dari tubuh, ia akan tetap"survive" setelah kematian.

Dengan demikian, meskipun dalam hal tertentu para filosof muslim berbeda pandangan, seperti tentang apakah jiwa itu sudah ada sebelum tubuh, atau ada bersamaan dengan tubuh, namun mereka sepakat bahwa pada fase perkembangannya lebih lanjut, jiwa akan tetap bertahan hidup (survive) setelah kematian, untuk selanjutnya mempertanggungjawabkan dan menerima akibat-akibat perbuatannya. Silang pendapat yang terjadi di kalangan para filosof Muslim, tidak sampai menodai hal-hal yang paling fundamental dalam psikologi mereka, terutama tentang keyakinan akan immaterialitas jiwa dan keadaannya yang akan tetap survive setelah kematian.

\section{Penutup}

Karakteristik utama psikologi yang berkembang dalam tradisi keilmuan Islam baik yang bercorak religius, sufistik, maupun filosofis adalah kesepakatan pandangan para tokohnya bahwa jiwa manusia bukanlah fisik atau bagian dari fisik, juga bukan sekadar fungsi neurologis otak -sebagaimana yang dikemukakan psikolog modern- tetapi merupakan substansi immaterial (al-jawhar al-rubani) yang tidak akan mati (hancur) setelah kehancuran badan. Ia akan terus hidup di alam akhirat untuk mempertanggungjawabkan perbuatan-perbuatan (amal-amal) mereka, baik berupa kebahagiaan atau penderitaan, tergantung pada jenis amal mereka selama meniti karir dunianya.

Pandangan psikolog Muslim di atas, jauh berbeda dengan pandangan psikologi modern yang telah mempersepsi jiwa sebagai tidak lain daripada sekedar fungsi neurologis otak, sehingga ketika otak seorang manusia mati atau hancur dalam peristiwa kematian, seluruh eksistensi manusia tersebut akan berakhir. Tidak ada lagi yang "survive" setelah kematian untuk mempertanggung-jawabkan perbuatanperbuatannya di akhirat nanti.

Dengan persepsi tentang jiwa yang seperti itu, psikologi modern sulit untuk dapat diharapkan mampu mengobati krisis spiritual yang dihadapi orang-orang modern. Karena sejak awalnya, ia telah tercerabut dari akar-akar spiritualnya. Pada posisi inilah psikologi Islam diharapkan menjadi alternatif yang menawarkan solusi terhadap krisis spiritual dunia modern. 


\section{Daftar Pustaka}

Ancok, Djamaluddin dan Fuad Nashori Suroso, Psikologi Islami Solusi Islam atas Problem-problem Psikologi, Yogyakarta, Pustaka Pelajar, 1994.

Badri, Malik B., Dilema Psikolog Muslim, terj. Siti Zainab Luxfiati dari judul asli, The Dillema of Muslim Psychologists, Jakarta, Pustaka Firdaus, 1986.

Baharuddin, Aktualisasi Psikologi Islami, Yogyakarta, Pustaka Pelajar, 2005.

Bastaman, Hanna Djumhana, Integrasi Psikologi dengan Islam: Menuju Psikologi Islami, Yogyakarta, Pustaka Pelajar, 1995.

CDRoom, Mausu'a $\underline{h}$ al- $\underline{H}$ adîts al-Syarîf, al-Ishdâr al-Tsânî, Global Islamic Software Company, 2000.

Diane E. Papalia \& Sally Wendkos Olds, Psychology, New York, Mc Graw-Hill, 1985.

Henry L. Roediger III, (et. al), Psychology, Boston, Little Brown \& Company, 1984.

Kartanegara, Mulyadhi, Integrasi Ilmu: Sebuah Rekonstruksi Holistik, Bandung, Arasy, 2005.

Menyibak Tirai Kejabilan: Pengantar Epistemologi Islam, Bandung, Mizan, 2003.

Psikologi Islam: Pengantar Psikologi Filosofis, Jakarta, Cipsi Publiser, 2007.

Mubarok, Achmad, Psikologi Qur'ani, Jakarta, Pustaka Firdaus, 2001.

.........,Konsep Nafs dalam Al-Qur’ân (Suatu Kajian tentang Nafs dengan Pendekatan Tafsir Maudhồ. Disertasi di program pascasarjana UIN Syarif Hidayatullah, Jakarta, 1999. 
Mujib, Abdul dan Jusuf Mudzakir, Nuansa-nuansa Psikologi Islam, (Jakarta: RajaGrafindo Persada, 2002.

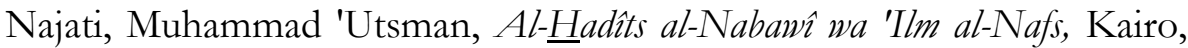
Dâr al-Syurûq, 1989.

Najati, Muhammad 'Utsman, Jiwa dalam Pandangan Para Filosof Muslim, terj. oleh Gazi Saloom, dari judul asli al-Dirâsât al-Nafsâniyyah 'inda al-'Ulamâ al-Muslimîn, Bandung, Pustaka Hidayah, 2002.

........., Al-Qur'ân wa 'Ilm al-Nafsî, Kairo, Dâr al-Syurûq, 1989.

Purwanto, Yadi, Epistemologi Psikologi Islami Dialektika Pendabuluan Psikologi Barat dan Psikologi Islami, Bandung, Refika Aditama, 2007.

Shaleh, Abdul Rahman \& Muhbib Abdul Wahab, Psikologi Suatu Pengantar dalam Perspektif Islam, Jakarta, Prenada Media, 2004. 